\title{
The EU at Stake? Changes in European Identification in Southern Europe and in Germany Following the Great Recession
}

\author{
Santiago Pérez-Nievas ${ }^{1, *}$ and Marta Paradés ${ }^{2}$ (D) \\ 1 Department of Political Science and International Relations, Faculty of Law, \\ Autonomous University of Madrid, 28049 Madrid, Spain \\ 2 Department of International Relations, Faculty of Humanities and Social Sciences, \\ Comillas Pontifical University, 28049 Madrid, Spain; mparades@comillas.edu \\ * Correspondence: santiago.pereznievas@uam.es
}

Citation: Pérez-Nievas, Santiago, and Marta Paradés. 2021. The EU at Stake? Changes in European Identification in Southern Europe and in Germany Following the Great

Recession. Genealogy 5: 51.

https://doi.org/10.3390/ genealogy5020051

Received: 18 March 2021

Accepted: 12 May 2021

Published: 18 May 2021

Publisher's Note: MDPI stays neutral with regard to jurisdictional claims in published maps and institutional affiliations.

Copyright: (c) 2021 by the authors. Licensee MDPI, Basel, Switzerland. This article is an open access article distributed under the terms and conditions of the Creative Commons Attribution (CC BY) license (https:// creativecommons.org/licenses/by/ $4.0 /)$

\begin{abstract}
This article looks at the evolution of European identification during the Great Recession in four Southern European "debtor" countries and in Germany. Although the crisis initially had a negative effect on European identification in the five countries, its medium-term impact was more severe in the Southern European countries than in Germany. While we find that microeconomic variables shed little light to account for these changes, we combine multilevel institutional and identitarian approaches to explain changes in European Identification. Following the multilevel institutional argument, attitudes might depend not only on citizens perceptions of institutional performance at the European level, but also on their perceptions of institutional performance at the national level; and they can operate through two mechanisms: citizens might transfer their positive (or negative) evaluations from the national to the European level, or, alternatively, they may substitute or compensate their negative national evaluations with positive evaluations of the European level. Our results indicate that both mechanisms were at work: at the peak of the Eurozone crisis, substitution effects-especially in the countries of the South-helped sustain European identification when it was at its weakest. However, transfer effects were also relevant to explain the recovery of European identification in two of the three countries in which the latter was greatest: Germany and Portugal. Following the identitarian argument, we find that the positive effect that national identification had on European identification previous to the Great Recession, had disappeared or weakened in four of the five cases by 2014. Nonetheless, this positive relationship had been fully restored in Germany and Portugal after the Great Recession, in 2017, signalling that the fading link between the two identifications might have been only temporary, at least in these two countries.
\end{abstract}

Keywords: European identification; national identification; great recession; Eurozone crisis; national evaluations; European evaluations; party system change

\section{Introduction}

The Great Recession, which began in 2008, had significant economic and political consequences. In economic terms, it was the worst crisis in Europe since the 1930s. Politically and institutionally, the European project suffered a dramatic loss of confidence, resulting in a striking increase in negative attitudes towards the EU (Paradés et al. 2013; Braun and Tausendpfund 2014), particularly in the Southern European member states (Verney 2017). In the first stage, the financial crisis led to a severe economic contraction in almost all European countries, but after 2010, it became a debt crisis characterised by the difficulties of some Eurozone countries to continue financing their deficits in the international financial markets. The debt crisis led to the implementation of austerity policies in public spending in Southern European countries and Ireland, with the consequent increase in unemployment, especially in Greece and Spain. 
What happened to European identification as a result of the Great Recession? Did European identification operate as a "reserve of legitimacy" in the face of the deterioration of other attitudes, such as confidence in the EU? This question is important given that various authors have pointed out that European identification can play a key role in correcting the EU's democratic deficit (Bruter 2003). The main purpose of this article is to examine changes in European identification before, during and after the Great Recession; while also analysing which factors have contributed to shaping it, and whether these changed as a result of the crisis. The article focuses primarily on Southern Europe where, due to the debt crisis, the economic crisis went for longer and was more severe; and where austerity policies were presented by some national governments, parties and the media as harsh impositions by the EU (Hobolt and Tilley 2014). More precisely we look at the longitudinal evolution, and determining factors at three points in time, of European Identification in the four largest Southern European countries: Italy, Spain, Greece and Portugal. Additionally, we also take Germany as a contrasting case with Southern Europe: here, there was also increasing opposition to the EU that grew from the perception that financial bailouts encouraged a corrupt, inefficient culture in the southern European countries to which the final responsibility for the debt crisis was ultimately attributed (Moravcsik 2012, p. 58). Additionally, together with the Southern European countries, Germany received more media attention for its relevant role during the Eurozone crisis. However, the economic depression was much shorter in Germany and much less harmful in terms of GDP growth and unemployment, which justifies its selection as a contrasting case with the four southern European member states.

Previous research has found that the decline in positive attitudes towards Europe could be due to citizens holding the EU responsible for poor national economic performance (Serricchio et al. 2013) or to negative citizens' evaluations of the functioning of European institutions (Dotti Sani and Magistro 2016). Although these approaches can explain some of this decline, we think they offer a limited picture of the factors behind the evolution of European identification during and after the Great Recession.

On the basis of previous research and the evidence provided in this article, we argue that the explanation for the decline (and recovery) of European identification is more complex. On the one hand, and despite a certain parallelism between the evolution of economic growth and that of European identification, we show that microeconomic variables contribute very little to explain European identification or its changes throughout the Great Recession. On the other, we argue that these changes are better explained by the specific circumstances of the national political crises that unfolded in each of our five countries as a result of the Great Recession. The timing, the intensity and the consequences of these crises varied greatly; not only distinguishing Germany from the rest, but also marking significant differences within the group of the four Southern European countries.

Following this idea of the singularity of each of the national political crises, our argument is divided into a multilevel institutional explanation and an identitarian explanation that works as a complementary argument. For the multilevel institutional explanation, we follow previous research that argues that citizens shape their attitudes towards the EU in a multi-level context, so that these attitudes might depend not only on citizens perceptions of institutional performance at the European level, but also on their perceptions of institutional performance at the national level (Anderson 1998; Sánchez-Cuenca 2000; Ares et al. 2017; de Vries 2018; Torcal and Christmann 2018). These multi-level spillover effects can operate through two mechanisms. Citizens might transfer their positive (or negative) evaluations from the national to the European level. Or alternatively, citizens may substitute or compensate their negative national evaluations with positive evaluations of the European level. Our argument in this article is that both mechanisms have been at work during the Great Recession. At the peak of the Eurozone crisis, substitution effectsespecially in the countries of the South-helped sustain European identification when it was at its weakest. However, transfer effects have also been relevant, in particular, to explain the recovery of European identification after the peak of the Eurozone crisis in 
two of the three countries in which European identification recovered most: Germany and Portugal. Nonetheless, these substitution and transfer effects did not take place in a vacuum but were intermediated by the national institutional crises that were triggered by the Great Recession in each of the five countries.

The identitarian explanation supplements the institutional one and is at the same time specifically suited to what distinguishes European identification from the remaining range of attitudes towards Europe. As we argue in the next section, European identification is at the core of the affective dimension of attitudes towards Europe. This would explain why so much of previous research on European identification has taken national identification as its main explanatory factor, while also arguing - in most cases - that the two identifications can be compatible. Following that research, our argument is that European identification develops within national contexts so that the affective ties and loyalties that bind European citizens together are, in turn, largely based on their respective national ties and loyalties. The evidence that we present in this article indeed confirms that, before the Great Recession, European identification was positively embedded within national identifications in all five countries. The Eurozone crisis, however, shattered this positive embeddedness in Germany and in three of the Southern European countries, at least temporarily.

Since we examine a limited number of cases, in our analysis below we cannot empirically demonstrate the connections we propose between the political and economic context of each of the five countries, on the one hand, and the impact of our individual-level variables, on the other. Nevertheless, we intend to systematically analyse the plausibility of the current theories of attitudes towards the EU in the light of our data.

In order to unravel the previous arguments and findings, this article is structured as follows. In the next section, we justify the selection of European identification and show its longitudinal evolution throughout the Great Recession. In Section 2, we present our theoretical framework and formulate our hypotheses. In Section 4, we describe in some detail the political context and the national institutional crises that were triggered by the Great Recession in each of the five countries. In Section 5, we present our data, justify our models, and present our results. We close the article with a brief concluding section.

\section{Why European Identification? The Evolution of European Identification throughout the Great Recession}

Research into attitudes towards the EU has grown exponentially since the 1990s, coinciding with the signing of the Treaty of Maastricht, although in the first phase it focused primarily on attitudes of support to integration and Euroscepticism (Hobolt and de Vries 2016, p. 415). However, in this paper, we focus on European identification for two reasons. First, apart from recent exceptions (Sanders et al. 2012; Westle and Segatti 2016; Isernia et al. 2012), European identification has been less studied than other European attitudes. Second, we think the analysis of European identification is particularly relevant at this time, given its potential to reinforce the stability of European institutions in the medium and long term (Hooghe and Marks 2008, p. 117). Previous work has underlined the importance of a common civic identity in resolving the so-called EU's democratic deficit (Fuchs 2011). In this respect, European identification can be a key component in the future development of the EU, especially in the wake of the institutional crisis of recent years.

However, the legitimating potential of European identification is a controversial issue in the literature and has not been empirically demonstrated (Fuchs 2011, p. 36). To some, European identification constitutes the core of the affective dimension of attitudes towards the EU (Fernández et al. 2016) that would play, in relation to European institutions, a similar role to that of national identifications in legitimising national political systems. For other authors, however, it is unlikely that a system of government as recent as that of the EU could have generated a European identification clearly distinguishable from other indicators of political support (Gabel 1998; Niedermayer and Westle 1995).

In relation to this dispute, Checkel and Katzenstein (2009, p. 216) point out how European identification relies on factors that are too weak or too recent to replicate the identity formation processes of the nation-state. Following this point of view, national 
identity with a shared history rooted in common experience, can become an obstacle to the emergence of a collective European identity (Fuchs 2011, p. 28). Other works, by contrast, argue that the two identifications can coexist, with European identification developing within the framework of national contexts (Bruter 2005; Díez Medrano 2003; Westle and Segatti 2016, p. 3).

With this debate in mind, we take European identification as a dependent variable. Although European identification has been studied from different perspectives and disciplines without a clear consensus on its content and nature (Isernia et al. 2012) we approach it as an affective attitude of belonging, "we-feeling", and loyalty (Westle and Segatti 2016, p. 96) that might have political consequences. Following Abdelal et al. (2009, p. 26), identities can affect conceptions of legitimacy, shared interests, policy options or preferences of political leaders and parties. In a context in which the future of the European project has been questioned more than ever before, European identification may play a key role in the legitimacy of the EU (Cerutti and Lucarelli 2008).

The study of the evolution of European identification is not easy given the many different questions that have been used to measure it in the main cross-national surveys. Some of these are: thinking of oneself as European, feeling of belonging, European versus national identification (the "Moreno-Linz question"), or feeling close to or feeling attached to Europe (Sinnott 2005; Isernia et al. 2012). Following Sinnott (2005), who considers it as the most appropriate measure, we take European attachment as our dependent variable. In the Eurobarometer surveys the question is formulated as follows: "Please, tell me how attached you feel to Europe: (1) Very attached (2) Fairly attached (3) Not very attached (4) Not at all attached". This we recoded into a dichotomous variable, contrasting those who feel very and fairly attached to Europe with those who do not feel very or at all attached.

Before moving on to our theoretical framework and analysis, we examine the longitudinal evolution of European attachment. Our expectation is that the Great Recession will have had had a negative impact on European attachment in all the countries, particularly those which suffered most from the economic consequences of the austerity policies, i.e., the Southern European countries. However, given that European identification develops within national contexts, it is also important to take into account the way in which Europe was traditionally framed-before the Great Recession-in each of our five member states. For this reason, we introduce a short description of how Europe was presented within the context of each country's historical experiences and national values before looking at the longitudinal evolution of European attachment.

In Germany, European identity was seen as an enlarged national identity that would help break up the association of German identity with the totalitarian Nazi regime (Díez Medrano 2003), by offering a modernised and inclusive version of it (Cram 2009, p. 105). In a similar vein, the political elites in Spain saw European integration as an opportunity to redefine Spanish identity, by breaking with the Franco period and associating the country with political and socio-economic modernisation (Díez Medrano 2003). Additionally, in Spain, there was also a strong pro-European consensus among elites at the time of accession (Alvarez-Miranda 1994, p. 164). Before the Great Recession, Europe was also framed in Italy as a key factor in the country's economic success and political stability (Malmborg 2002, p. 51). All in all, this is in accordance with the high levels of European attachment we find in the three countries before the Great Recession.

In Greece and Portugal, there was no comparable consensus on European integration to that of Spain at the time of accession, given the anti-European position that the socialists and communists of both countries initially adopted (Alvarez-Miranda 1994, pp. 159-60). This lack of initial consensus among the Greek and Portuguese elites helps to explain the successive versions of Europhobia and Europhilia that have characterised the recent political history of both countries (Tsoukalas 2002, p. 42; Soares 2007, p. 462). This is in accordance with the lower levels of European attachment we find in these two countries before the Great Recession. 
Figure 1 shows the negative impact of the Great Recession on levels of attachment to Europe in our five case studies, the Eurozone and the EU. As said, Germans, Spaniards and Italians reported higher levels of European attachment at the beginning of the series. From that point on, the trend shown by European attachment is negative in all five cases. However, whereas we see a sustained but moderate decline in the case of Germany, this is much steeper in the Southern European countries. From 2014 onwards two trends can be clearly distinguished in Southern Europe: while European attachment fully recovers in Spain and Portugal; it stagnates at relatively low levels in Greece and Italy-the latter being the most striking case because it moved from being the most Europeanist of the five to one of the most disaffected.
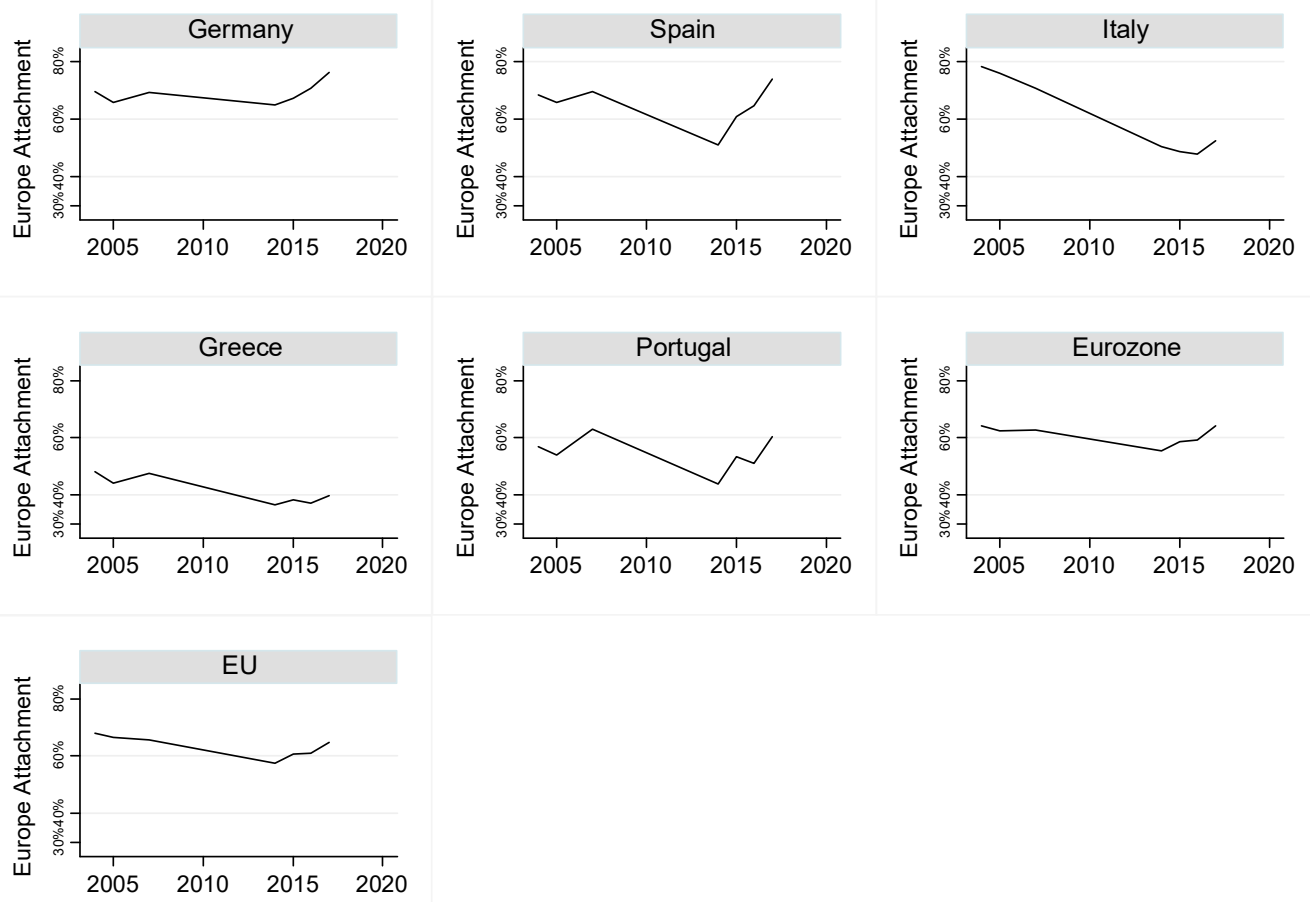

Figure 1. Evolution of attachment to Europe 2004-2017. Source: Own elaboration from Eurobarometer Note: Column percentage of attachment to Europe.

\section{Theoretical Approaches of European Identification: Research Hypotheses}

In this article, we focus on three theoretical approaches to explain European identification, although some of these have also been used to explain other attitudes towards the EU. Each of these approaches underlines factors whose relative weight in the explanation of European identification might have changed as a result of the Great Recession.

The first theoretical approach, known as rational-instrumental, has been more frequently associated with the explanation of support for European integration (Hobolt and de Vries 2016, p. 421). The greater emphasis on the economic dimension during the initial phases of European integration justifies that the early works on attitudes towards Europe focused on calculations of instrumental rationality on the cost and benefit of belonging to the EU, both in individual and collective terms (Eichenberg and Dalton 1993; Gabel 1998). Those individuals who perceive that they themselves or their respective countries benefit from belonging to the EU will show higher levels of European identification. Following this approach, explanatory factors may be individual characteristics such as, occupation (unemployment), income level, or educational level, which offer individuals comparative advantages to position themselves as "winners" or losers" in the integration process (Gabel 1998); or they may be linked to economic evaluations, which will be egocentric per- 
ceptions when the individual assesses his/her personal economic situation, or sociotropic perceptions when the calculation of cost and benefit is made with respect to the country's membership of the EU (Hooghe and Marks 2005, p. 421).

Generally speaking, we would expect that these factors linked to the rational-instrumental approach will contribute to explain European identification. However, the Great Recession restored the visibility of the economic side of the European project by underlining the material consequences for the winners and losers of integration, particularly in countries that had to implement austerity measures. Therefore, we expect that:

Hypothesis 1 (H1). The impact of the variables of the rational-instrumental approach will be greater or more frequent after the Great Recession $(2014,2017)$ than before it (2004).

Hypothesis 1 (H1.1). The impact of the economic variables following the Great Recession will be greater in southern European countries.

Our second theoretical framework has been known as the heuristics or institutional approach (see for instance Sanders et al. 2012, p. 12). The simplest and earliest version of this argument is that, since most citizens lack sufficient knowledge about the European level, they rely on national proxies or heuristics to structure their views on Europe (Anderson 1998; de Vries 2018, p. 27). Some of these heuristics include democratic governance (Sánchez-Cuenca 2000), democratic satisfaction (Rohrschneider 2002), national institutional trust (Anderson 1998) or partisan identification (Ray 2003).

However, there is no consensus in the literature on how and through which mechanisms these various heuristics operate. While Anderson (1998) suggests that people's evaluations of national conditions serve as a proxy to deal with information shortfalls about the EU, Sánchez-Cuenca (2000) conceives them as a lens through which people view the benefits of more political and economic integration. These different conceptions lead to opposite expectations: citizens who hold positive national evaluations will also have positive attitudes towards the EU; or alternatively citizens may perceive the EU in a compensatory manner, so that attitudes towards the EU are more positive when national evaluations are more negative, especially in countries with low democratic quality (Sánchez-Cuenca 2000, p. 7). Therefore, national proxies can work as either transfer or substitution heuristics which operate in opposite directions (Sanders et al. 2012, p. 12). Following this controversy, the more recent work by Ares et al. (Ares et al. 2017, p. 1096) has updated the concept of transfer effects with the hypothesis that dissatisfaction with European institutions may be the consequence of a "syndrome of dissatisfaction with national governments". Other works find that, even if the national arena still has a predominant effect on attitudes about the EU, "evaluations of EU performance are an important covariate, indicating that positive $\mathrm{EU}$ evaluations could counterbalance the deterioration process with regard to perceptions of national institutions" (Torcal and Christmann 2018, p. 15)

The second controversy in this approach is related to the direction of causality. While early works assumed that it is national proxies that affect attitudes towards Europe, more recent research argues that not only national perceptions can serve to structure peoples' views towards Europe, but the opposite may also happen, in a game of reciprocal influences. The greater visibility of the EU during the Eurozone crisis might have contributed to reinforcing these reciprocal influences (de Vries 2018, p. 34). Following this idea, De Vries' benchmark theory of EU scepticism relies on the concept of the EU differential that citizens use as a reference or benchmark to weigh up their evaluations of the perceived benefits from the status quo-being part of the EU-against those associated with an alternative state-seceding from the EU (de Vries 2018, pp. 33-42). Citizens use the comparison between their perceptions of the EU with their perception of the national arena-through cues such as government evaluations-as a benchmark to form an opinion about their countries' continued membership in the EU.

In fact, the Eurozone crisis may shed light on how these mechanisms can work. In Southern European countries, the EU was blamed for imposing austerity measures that 
exponentially increased unemployment rates, so EU evaluations worsened during the Eurozone. However, evaluations of the national government in these countries may have decreased even more if citizens held their national governments as ultimately responsible for the debt crisis; or if, as a result of the unravelling of corruption scandals during the Great Recession-as happened in Spain. In this case, the EU differential would be a positive net effect for the EU which, in turn, would have a positive impact on levels of European identification.

By contrast, in Germany, the EU might have been blamed for being too lax towards highly indebted member states. At the same time, these perceptions of economic and political mismanagement in the South may have worked to improve citizens' evaluations of their own national government and policies. The EU differential in this case would be a positive net effect for the national level which, in turn, will have a negative impact on levels of European identification. This would explain why support for Eurosceptic parties also increased in Germany during this period (see below): Eurosceptic parties stress the quality of national conditions vis-à-vis the EU as a whole and question the benefits of membership (Otjes and Katsanidou 2017; de Vries 2018, pp. 39-40).

Thus, following the heuristics or institutional approach, we propose two sets of different hypotheses:

Hypothesis 2 (H2). Citizens transfer their evaluations of the national level to the European level. Thus, citizens with higher levels of confidence in their national government will also show higher levels of European identification.

Hypothesis 3 (H3). Citizens substitute or compensate their evaluations of the national level with their perceptions of the EU level; and vice versa. So those who hold a positive evaluation of the EU, but not of their national government, will show higher levels of European identification; whereas those who hold a positive view of their national government, but not of the EU, will show lower levels of European identification.

The argument about substitution or compensation heuristics was originally made for countries with low evaluations of national performance (Sánchez-Cuenca 2000), so we also expect

Hypothesis 3 (H3.1). Substitution or Compensation effects will have a greater effect in Southern European countries, and show a greater impact during or after the institutional crisis that was triggered by the Great Recession, than before it.

Our third and final approach, the identitarian approach, emerged in the late nineties, after the Treaty of Maastricht, when the process of European integration began to move from an economic to a more political sphere. Generally speaking, this approach gives national identification a key role in the development of European identification. Nonetheless, we find in the literature different ways of understanding the relationship between the two identifications. The first group of authors tended to underline the incompatibility or exclusivity of European and national identity by arguing that they compete in a zero-sum game (Carey 2002; McLaren 2006). However, most research following the identitarian approach argues that the two identifications can be complementary, on the premise that the simultaneous development of multiple identifications is possible (de Vries and van Kersbergen 2007; Risse 2010, p. 45; Westle and Segatti 2016, p. 97). Empirical evidence from political psychology tends to support the idea that national, subnational and European identifications are largely inclusive and can coexist with relative ease, although it is not clear what the break-even point is for them not to come into conflict (Sanders et al. 2012, p. 17). Following this latter research, we take as a departure point the idea that European and national identifications are combined, which implies that European identification can have different meanings within different national contexts (Westle and Segatti 2016, p. 143). In the previous section, we briefly revised how Europe was framed 
with different meanings following the diverse historical legacies and national values of each of our five case studies. This previous research suggests that the relationships between national and European identifications are contingent and contextual, giving support to the idea that these might have changed during and after the Great Recession.

The growth of Eurosceptic parties, which we will examine in greater detail in the next section, placed the European project as antagonistic to what was presented as the national interest, so our expectation is that:

Hypothesis 4 (H4). the Great Recession will have contributed to reinforcing the incompatibility between national identifications and European identification, so where the relationship was positive before the Great Recession (2004) it will have weakened, become not significant, or even negative after the Great Recession (2014, 2017).

In relation to this last hypothesis, we do not necessarily expect different effects in Germany in relation to Southern Europe. Once the Great Recession entered the phase of the Eurozone debt crisis, it turned into an institutional and political crisis as much as an economic one, with the emergence or strengthening of Eurosceptic parties that brought into question the European project with varying degrees in Southern European countries and Germany. In the next section, we argue that the unravelling of that political crisis was different in each of our five countries, turning into national institutional crises that had diverse implications for European identification in each of our five cases.

\section{Institutional Crisis and Party System Change in Germany and in Southern European Countries during the Great Recession}

Although the Great Recession started as an economic crisis after the fall of Lehman Brothers, it turned into an institutional crisis that led to governmental instability and the transformation of national party systems at different paces and in varying degrees. A shifting cleavage structure accompanied by growing feelings of anti-globalisation (Kriesi et al. 2006) - and therefore of anti-EU sentiments-meant that a severe economic crisis related to the EU was almost bound to lead to the rise or the strengthening of antiEuropean, populist, parties. This new Europeanisation cleavage was reflected above all in the good results of both hard and soft Eurosceptic parties in the 2014 European Parliament elections (Treib 2014). However, the impact of this new cleavage varied greatly from country to country, and not all party system change was related to the growth of Euroscepticism (Rama 2019). In the following paragraphs, we discuss the short and medium-time effects of the crisis on government stability and party system transformation in each of our five countries.

Greece, at the heart of the Eurozone crisis and the first country to need a bail-out, is where the political effects of the Great Recession began earlier and have possibly been most pronounced. Cabinet stability was very low from the start of the crisis, and there were five general elections between 2009 and 2015. In 2012 the centre-left Pasok party was substituted by the soft Eurosceptic challenger Syriza as the main party of the left. Increased party fragmentation meant that single-party governments-predominant since democratization-were substituted by more unstable coalitional governments. Last but not least, several parties_-including Syriza-occupy the Eurosceptic space across the left-right spectrum, making Greece (together with Italy) the country with the greatest growth of Eurosceptic parties.

In Italy, Berlusconi's government was forced out of office at the height of the debt crisis by massive European pressure and was replaced by the technical government of Mario Monti who initiated a program of reforms. The debate over austerity measures played an important role in the 2013 General election in which the populist and hard Eurosceptic Five-Star movement made an astonishing breakthrough. This led to the transformation of the Italian party system and resulted in difficulties in government formation and cabinet instability. The post-recession Italian party system also stands out for having a fullyfledged anti-European segment across the left-right spectrum. The Lega Nord and other 
minor radical right-wing parties have clearly moved towards a very pronounced antiEuropean position, whereas the hard Euroscepticism of the Five Start Movement occupies an "ideologically blurred" position.

In Spain, dissent with the policies of austerity was in its first stage contained within the party system through government alternation. In the following years, with the worsening economic situation and the revelation of numerous cases of corruption, the traditionally stable Spanish system began to disintegrate and two major parties, the left-wing Podemos and the centrist-right Ciudadanos, broke through, first in the 2014 European elections and then in the 2015 General elections (Orriols and Cordero 2016). This profoundly transformed the mechanics of the previous system leading to difficult government formation and cabinet instability. Spain also stood apart because of the scarce presence of Euroscepticism in the new party system until the more recent emergence of Vox in 2018 (i.e., after our last observation). In its initial stages Podemos might have been labelled, at the most, as "softly Eurosceptic", a position that the party subsequently moderated; whereas Ciudadanos' pro-EU positions were even more explicit than those of the two mainstream parties.

Portugal is the most exceptional of the four European Southern countries in that no successful new party emerged throughout the Great Recession. The bail-out of 2011 was backed by the three main governmental parties of the centre right and centre left, so most anti-austerity opposition was basically channelled through the two traditional radical left-wing parties, the $\mathrm{CDU}$ and the $\mathrm{BE}$, which moderately gained votes during the crisis while they also accentuated their anti-EU stance. Although there was an alternation of government in 2015, Portugal also stands out among Southern European countries for its greater government stability during and in the years immediately after the crisis.

By contrast, the most striking feature of the German party system was its governmental stability through the Great Recession. Angela Merkel and the CDU/CSU remained in office under different coalitions throughout the entire crisis and after. There was, however, a major upheaval with the emergence of the populist right-wing AfD. Founded shortly before the 2013 Bundestag elections as an initially neo-liberal Eurosceptic right-wing party, the AfD won seats in all the Land elections that it contested in 2014 and made an important electoral breakthrough in the European Elections of that same year. The AfD gained a second much stronger life in the wake of the refugee crisis, which reached its peak in the latter part of 2015, moving further to the right, and finally achieved representation in the 2017 Bundestag elections.

Thus, despite some common traits, consequences in terms of government formation and cabinet stability were different in timing and intensity: the negative effects in this respect were manifest at a very early stage in the case of Greece, slightly later in Italy, and only by late 2015 in Spain. By contrast, there was much greater cabinet stability in Germany and Portugal. Since government stability is likely to be a good predictor of evaluations of political performance at the national level we take this as a relevant contextual factor that can influence transfer and substitution effects in explaining European identification at different points in time.

Also, although there was a strengthening of the Europeanization cleavage across Western Europe this reached very different degrees in each of our five cases. Its impact was great in Greece and Italy, leading to a complete reshaping of their respective party systems; a little milder in Germany and involving only the right-wing ideological space; moderate in Portugal, involving only a hardening of the anti-EU positions of the parties of the radical left; and practically non-existent in Spain (only from 2018 onwards, i.e., after our last observation). Previous works have pointed out that the degree of politicisation of European integration within the national party system should have an influence on diffuse support for Europe (Ares et al. 2017, p. 1098). Equally, it should also have an impact on the relationship between national and European identification, weakening that relationship where the growth of Eurosceptic parties has been greater $(\mathrm{H} 4)$.

In order to better assess the political contextual framing in which transfer or substitution effects might have affected European identification at different times of the period assessed, 
we combined (in Figures 2 and 3) respondents' answers to two Eurobarometer questions ("For each of the following media and institutions, please tell me if you tend to trust or tend not to trust: (a) The (National) Government, (b) The European Union") to show the evolution of citizens' institutional confidence following four parameters: (1) those who have confidence in their national government, but not in the EU; (2) those who have confidence in the EU, but not in their national government; (3) those who have confidence in neither; (4) those who have confidence in both. Figure 2 shows the evolution of these four parameters for the four Southern European countries, whereas Figure 3 does it for Germany.
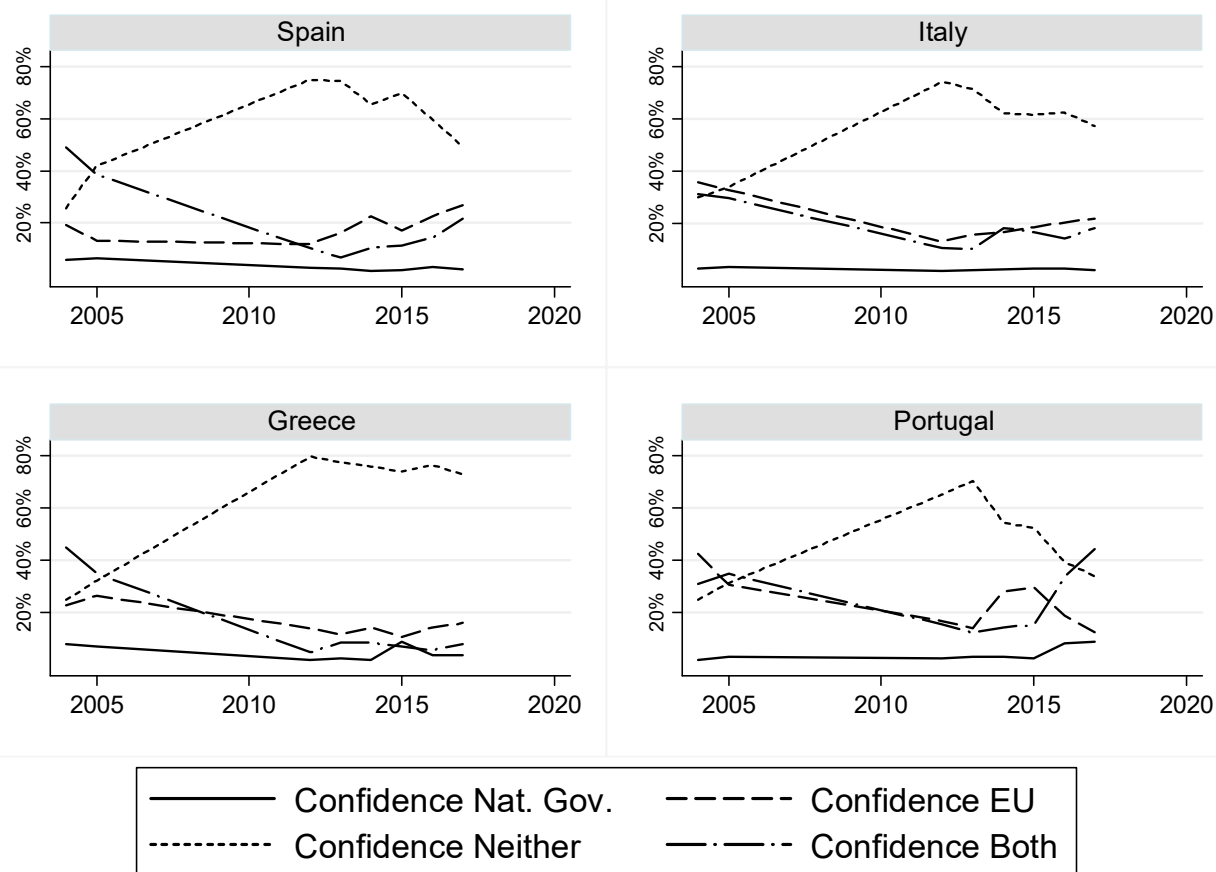

Figure 2. Evolution of the confidence in the national government, the EU, in both, and in neither, in Spain, Italy, Greece and Portugal (2004-2017). Source: Own elaboration from Eurobarometer Note: Column percentage of differential confidence (variable created taking into account confidence in national government and confidence in EU).

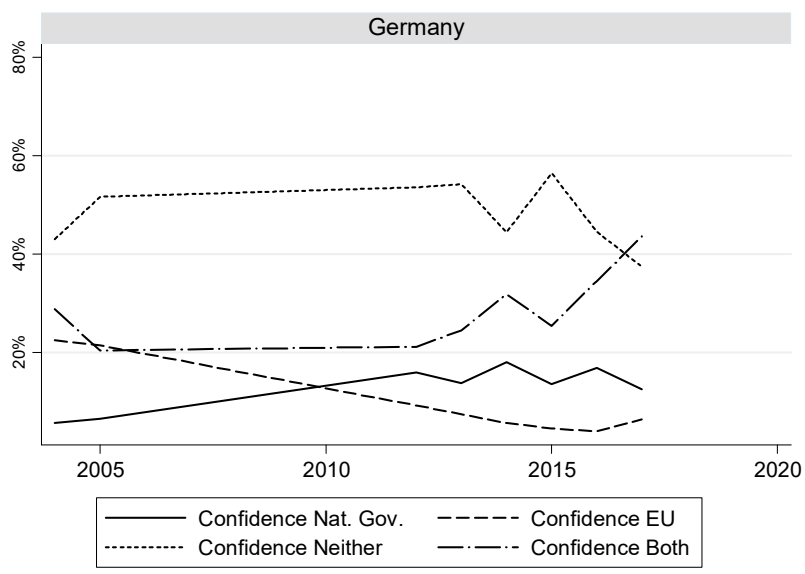

Figure 3. Evolution of the confidence differential in the national government, the EU, in both, and in neither, in Germany (2004-2017) Source: Own elaboration from Eurobarometer Note: Column percentage of differential confidence (variable created taking into account confidence in national government and confidence in EU). 
The first thing that stands out is the similarity between the four Southern European countries (at least until 2013/14) in contrast with Germany. In the four southern European countries, the Great Recession brought with it a sharp decline in confidence both in national governments and the EU at least until 2013. Only after that year-coinciding with the stabilisation of the Eurozone crisis-did EU positive evaluations begin to grow to the detriment of the double lack of confidence: very clearly in Portugal and Spain, somewhat more modestly in Italy, and very marginally in Greece. Following H3 from the heurestics approach above, it would be from that year that substitution effects might have a positive effect on European identity, particularly in Portugal and Spain, where confidence in the EU recovered the most. However, from 2015 onwards the singularity of Portugal in relation to the other three countries must also be underlined: the recovery of confidence in the national government-either on its own or within double confidence-makes this country more similar to Germany, after that year, than to its southern neighbours.

By contrast with the European countries, in Germany, the double lack of confidence predominated in 2004, possibly reflecting the economic crisis that the country was undergoing at the time. In the early years of the Great Recession, this double lack of confidence remains predominant, while the percentage of those who had confidence only in the national government gradually increases, and the percentage of those who had confidence only in the EU decreases. From 2013 to 2017, the double lack of confidence falls in favour of the double confidence, while those with confidence only in the national government finish the series at moderately higher levels than at the beginning. In short, in Germany, there was an increase in confidence only in the national government in the years following the Eurozone crisis, but this growth was modest. From 2013 onwards, what predominates in Germany is the increase in double confidence. Thus, for the German case-and for the Portuguese from 2015 onwards-it is not clear what the effect of the strengthening of national evaluations should be: on the one hand, following the transfer Hypothesis (H2), the positive assessment of the national level might positively revert on European identification; on the other hand, however, following the substitution Hypothesis (H3) and De Vries' benchmark theory, if national government evaluations grow at the expense of confidence in the EU they might negatively affect European identification. We will revise these expectations in our section on results.

\section{Data, Models and Results}

In our analysis, we examine European attachment at three different points in time. We selected the year 2004 for the pre-crisis observation and the year 2014 as the observation closest to the peak of the Eurozone crisis. In addition, we also added an observation, the year 2017 (after the Great Recession) in order to test whether potential changes might be attributed to contingent effects resulting from the peak of the crisis, or might respond to more far-reaching structural changes. This selection was also conditioned by the availability of data since these three points in time were the only three years of the longitudinal series for which the dependent and all independent variables had been included in the Eurobarometer surveys. We could not select the 2007 study as a departure point due to a lack of data for key independent variables. On the other hand, the choice of 2014 as the year closest to the peak of the Eurozone crisis was conditioned by the availability of data on the dependent variable. The three surveys have been merged into a single database in order to use the year of observation as an independent variable and to check whether or not we observe changes for the different years analysed.

Our dependent variable is European identification measured as an attachment to Europe recoded into a dummy variable: those who feel very and fairly attached to Europe versus those who do not feel very attached or not at all attached (the description, measurement and descriptive statistics of all variables included in our analysis can be checked in Appendix A).

To verify our hypotheses, we included in our models the following variables. First, expectations about the national and personal economy (those who consider that their eco- 
nomic situation or that of their country will get worse), the educational level (considering those who were 20 or more years old when they finished their studies, which we take as a reference of those with higher education versus the rest) as well as being unemployed, allow us to test the hypotheses of the rational-instrumental approach.

For the heuristics approach, we use as an independent variable the institutional variable with four categories that we examined longitudinally in the previous section. As we mentioned before, this variable combines respondents' answers to two Eurobarometer questions: confidence in the EU and confidence in the national government resulting in four categories: (1) those who have confidence in their national government, but not in the EU; (2) those who have confidence in the EU, but not in their national government; (3) those who have confidence in neither; (4) those who have confidence in both. In order to assess our hypotheses on transfer or susbstitution effects, we include in our analysis this variable with "lack of confidence in either level of government" as the reference category. In our logistic regression results below we interpret statistically significant effects of category 1 as confirmation of transfer effects, whereas those of category 2 we read as confirmation of substitution effects, and those of category 3 as a more ambiguous combination of both. We assume that substitution effects will always be positive, whereas transfer effects might be positive or negative (although, in fact, we only find positive transfer effects: see below)

Following the identitarian approach, we include in the analysis attachment to the nation as a dummy variable: those who feel very or fairly attached to their nation versus those who do not feel very or at all attached. Finally, we included age (as continuous), gender (with women as the reference category) and ideology on a scale from 1 (left) to 10 (right) as control variables.

Since our dependent variable is a dummy, we carried out logistic regression analyses in each of the five countries (Germany, Spain, Italy, Greece and Portugal) so we can compare the results across countries. In order to check if differences are observed before, during or after the Great Recession, we carry out interactions between our independent variables of interest and the year of study. However, we start showing a base model without interactions and with standarised variables, which allows us to compare the effects between our independent variables (Figure 4).

The results confirm our expectation about the negative effect of the Great Recession on European identification. The year 2014, compared to 2004, has a negative effect on European attachment in all five countries with the only exception of Greece. The inclusion of 2017 allows us to test whether the negative effects of the crisis are contingent on the crisis itself or persist in the medium term. The negative effect vanishes in Spain and Portugal but it appears in Greece, and it aggravates in Italy, the two countries where European attachment stagnated at low levels after the peak of the Eurozone crisis, as seen in the longitudinal analysis. A negative effect of 2017 is also observed in Germany, but this is weaker when compared to those of Greece and Italy. Additionally, the non-effects for Spain and Portugal in 2017 suggest a full recovery of European attachment in the two Iberian countries.

To test our hypotheses at different points in time, we focus on what is the average marginal effect (from now on, AME) of our independent variables on European identification for each of the three observations over time $(2004,2014,2017)$. Thus, the AMEs of the regression models describe the impact of the interaction of our independent variables* years. In order to facilitate the reading, we present our main results in Figures 5 and 6: the effect of each of our independent variables on the probability of being attached to Europe is positive when the value is above 0 , or negative when it is below 0 . If the confidence levels overlap with 0 , the effect will be understood not to be statistically significant. However, due to space limitations, we show in figures only our most prominent results, and we summarise all results in Table 1. (AMEs graphs for all the independent variables shown in Table 1 are at the disposal of those interested upon request.) We test our hypotheses in the same order as that of the theoretical framework. 


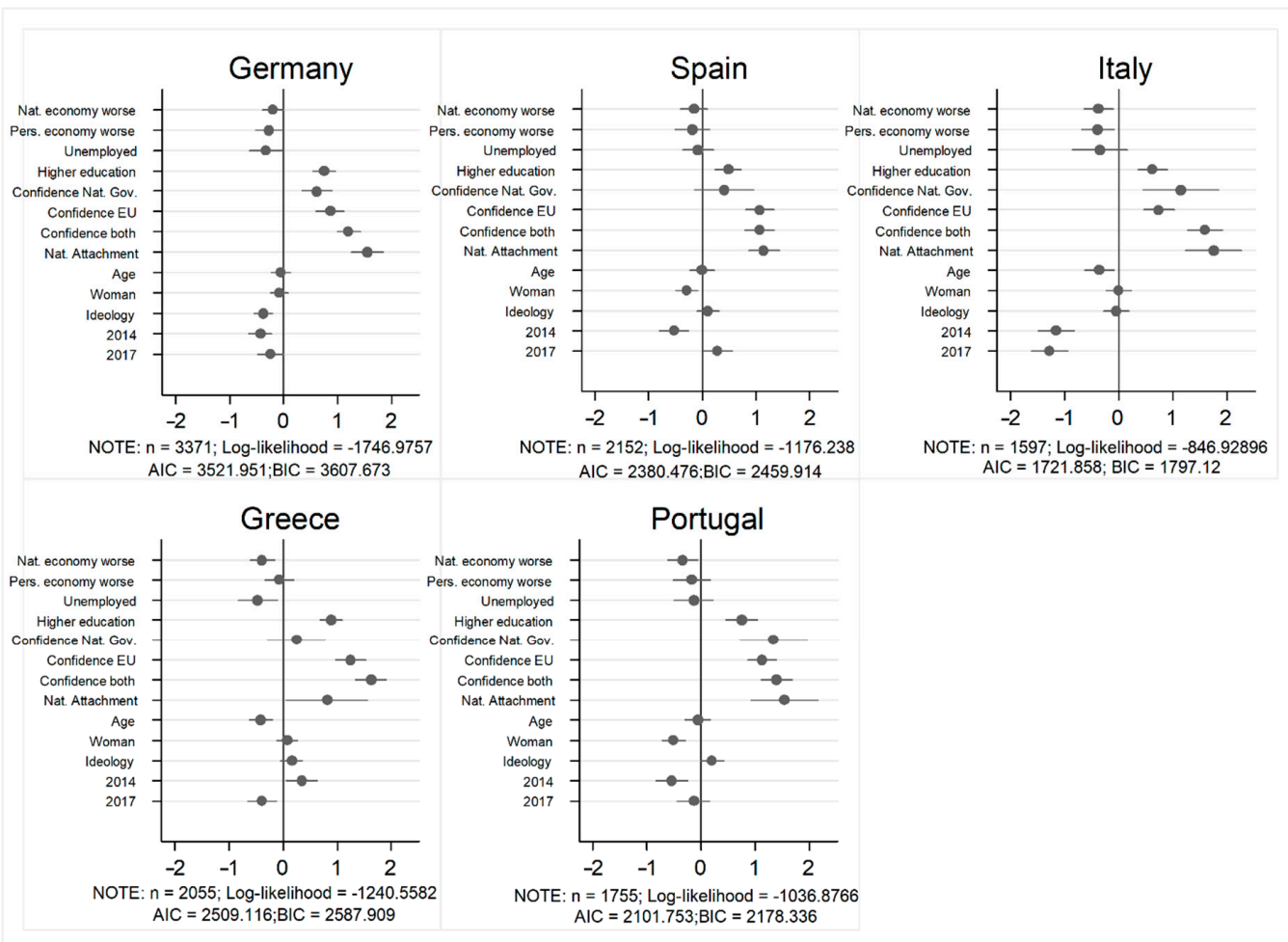

Figure 4. Coefficients of the logistic regression base model on attachment to Europe in Germany, Spain, Italy, Greece and Portugal. Source: Own elaboration from Eurobarometer Note: Logistic regression results. Variables standardized in each country. Crossing the zero line indicates that the differences are not statistically significant.
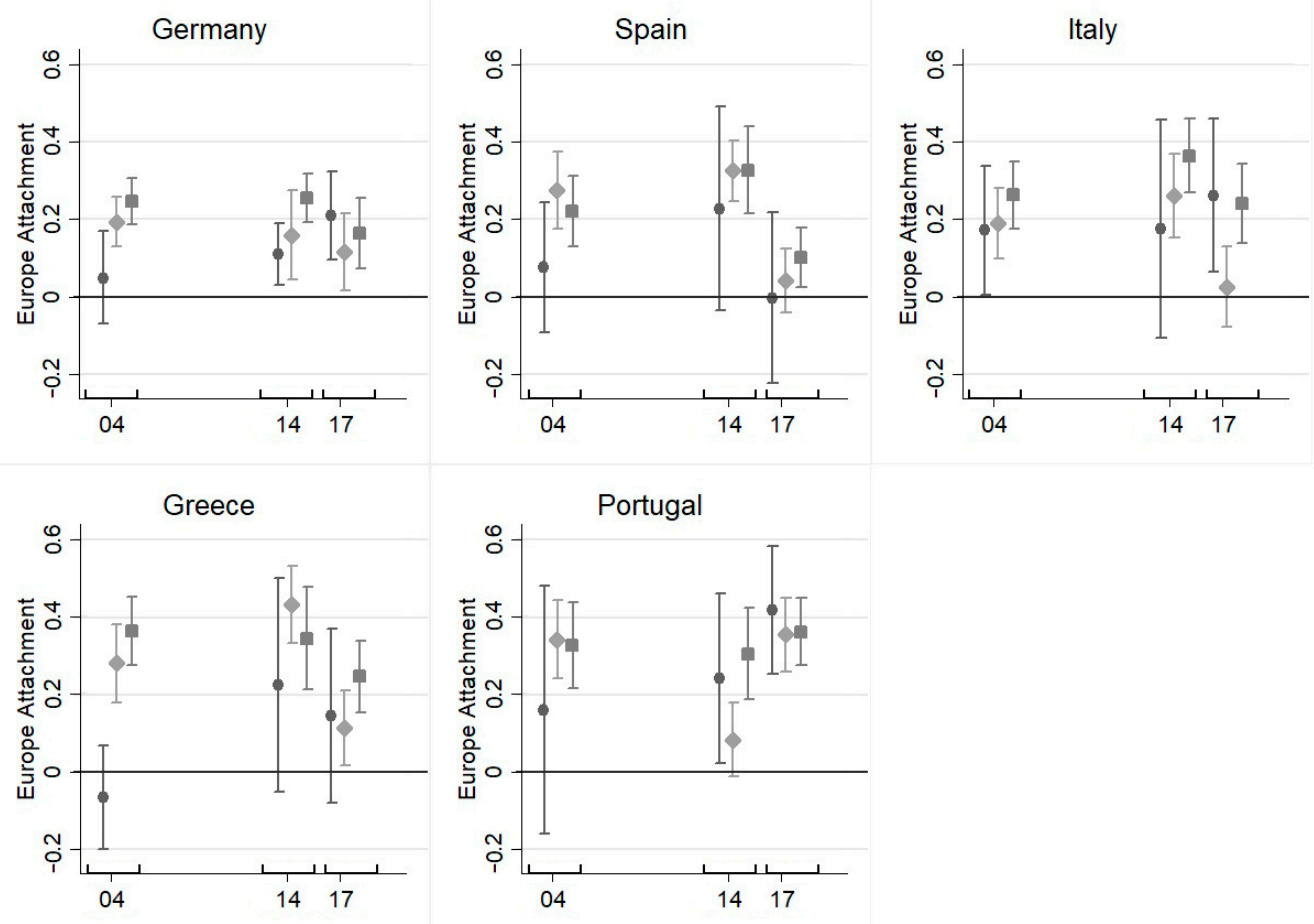

- Confidence Nat. Gov. Confidence EU
Confidence both

Figure 5. AMEs of the confidence in national government, the EU and both (with respect to confidence in neither) in the probability of attachment to Europe by year, with 95\% CIs. Source: Own elaboration from Eurobarometer. 

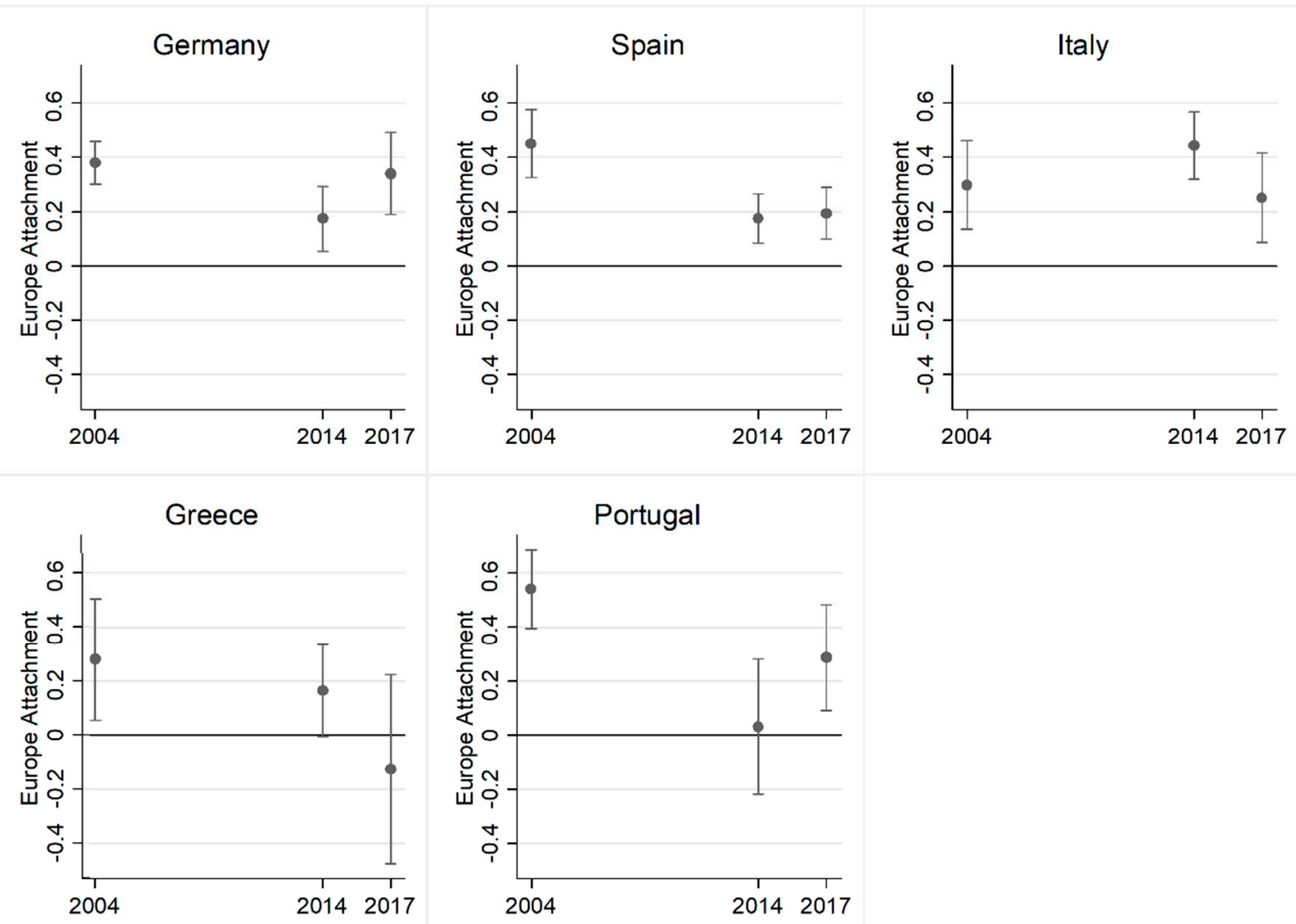

Figure 6. AMEs of the attachment to the nation in the probability of attachment to Europe by year, with $95 \%$ CIs. Source: Own elaboration from Eurobarometer.

Table 1. Summary of results for attachment to Europe.

\begin{tabular}{|c|c|c|c|c|c|c|c|c|c|c|c|c|c|c|c|c|c|c|c|c|c|c|c|c|}
\hline & \multicolumn{3}{|c|}{$\begin{array}{l}\text { Personal Economy } \\
\text { Worse }\end{array}$} & \multicolumn{3}{|c|}{$\begin{array}{l}\text { National Economy } \\
\text { Worse }\end{array}$} & \multicolumn{3}{|c|}{ Be Unemployed } & \multicolumn{3}{|c|}{ Higher Education } & \multicolumn{3}{|c|}{ Confidence Nat. Gov. } & \multicolumn{3}{|c|}{ Confidence EU } & \multicolumn{3}{|c|}{ Confidence In Both } & \multicolumn{3}{|c|}{ National Attachment } \\
\hline & 2004 & 2014 & 2017 & 2004 & 2014 & 2017 & 2004 & 2014 & 2017 & 2004 & 2014 & 2017 & 2004 & 2014 & 2017 & 2004 & 2014 & 2017 & 2004 & 2014 & 2017 & 2004 & 2014 & 2017 \\
\hline Germany & ns & ns & - & ns & ns & - & ns & ns & - & + & + & + & ns & + & + & + & + & + & + & + & + & + & + & + \\
\hline Spain & ns & ns & ns & ns & ns & ns & ns & ns & ns & ns & + & ns & ns & ns & ns & + & + & ns & + & + & + & + & + & + \\
\hline Italy & ns & ns & ns & ns & ns & ns & ns & ns & ns & + & + & + & + & ns & + & + & + & ns & + & + & + & + & + & + \\
\hline Greece & ns & ns & ns & - & ns & - & ns & ns & - & + & + & + & ns & ns & ns & + & + & + & + & + & + & + & ns & ns \\
\hline Portugal & ns & ns & ns & ns & ns & - & ns & ns & ns & + & + & ns & ns & + & + & + & ns & + & + & + & + & + & ns & + \\
\hline
\end{tabular}

ns: not significant; +: positive effect; -: negative effect on the likelihood of Europe attachment.

Starting with $\mathrm{H} 1$ from the rational-instrumental approach, we can provide very little evidence that economic perceptions and sociodemographic variables (unemployment, educational level) have an effect on European identification or that this might have strengthened after the Great Recession. Personal economic expectations only have a negative effect in Germany (2017). H1 works slightly better for national economic expectations: we see negative effects in Germany, Portugal, and Greece (2017) although in the latter case there were also negative effects before the crisis. We can see changes in the effect of the educational level only in Spain (2014). Being unemployed had a negative effect after the crisis only in Germany and Greece (but only in 2017: see Table 1 for all these results). In sum, the effects of the economic variables on European identification are slightly more frequent after than before the crisis; however, there is the paradox that most of these effects concentrate in 2017, and they more frequently involve Germany than any other country (evidence that serves to refute H1.1). All in all, microeconomic factors seem to explain very little of the change in European identification that we observe during the Great Recession.

Moving now to $\mathrm{H} 2$ and $\mathrm{H} 3$ from the heuristics approach Figure 5 shows the effects of confidence only in the national government; confidence only in the EU; confidence in both, with lack of confidence in either as the reference category. Prior to the Great Recession, 
evidence suggests that substitution effects (H3) were more relevant than transfer effects (H2): in 2004 confidence only in the national government had a positive effect only in Italy. By contrast, double confidence and confidence only in the EU had positive statistically significant effects in all countries. After the Great Recession, the results are more varied. We can divide our five countries into three groups according to the type of effects: Germany and Portugal, on the one hand; Spain and Greece, on the other, and Italy as somewhat in between these two groups of countries.

In Germany and Portugal, the transfer hypothesis seems to predominate after the crisis even more so in 2017 than in 2014 (especially in Portugal). Confidence only in the national government has a positive effect on European attachment in both years. Although the reference category is lack of confidence with both levels, we must remember that confidence only in the national government is operationalised in opposition to lack of confidence in the EU: thus, its positive effect denotes that the German and the Portuguese attachment to Europe are very much rooted on their positive assessments of the national level, at least after the Great Recession. As we saw in Figures 2 and 3, after the peak of the Eurozone crisis, there was a strengthening of confidence in the respective national governments of Germany and Portugal, so these positive effects are congruent with the higher levels of European identification we find in the two countries at the end of the period.

In Spain and Greece, by contrast, substitution effects seem more relevant, particularly during the peak of the crisis, in 2014. On the one hand, confidence only in the national government does not have positive effects either before or after the crisis. On the other, confidence only in the EU does in 2014. In 2017, however, confidence only in the EU ceases to be significant in the case of Spain, and weakens very significantly in Greece.

Italy looks more like Spain and Greece in the sense that substitution effects were reinforced during the peak of the crisis: confidence only in the national government has an effect in 2004 but not 10 years later. In 2017, however, confidence only in the national government becomes positively significant again —and in this respect, Italy resembles more Germany and Portugal, whereas confidence only in the EU loses its statistical significance. Nonetheless, it must be remembered from Figure 3 that - unlike Portugal and Germanyconfidence only in the national government and double confidence in Italy remained at very low levels after the peak of the crisis, which would explain why European identification stagnates in Italy.

Finally, doing a general revision of $\mathrm{H} 3$ and H3.1, we can say that substitution effects were reinforced in Southern Europe as a result of the Great Recession. However, this was only the case during the peak of the crisis, in 2014, and there is the partial exception of Portugal where transfer effects were at least as important in sustaining European identification. Finally, the substitution hypothesis only works with regard to positive EU evaluations and in no case-not even in Germany-do we find confidence only in the national government to have a statistically significant negative effect on European attachment.

We conclude this section by revising the $\mathrm{H} 4$ linked to the identitarian approach (Figure 6). In 2004, the effect of national attachment on European attachment was positive and strong in Germany, Spain, and Portugal and-although somewhat lower-also positive in Italy. This positive effect was weaker in Greece, possibly as a result of the greater traditional division among Greek elites with respect to the EU.

Looking at the subsequent evolution, $\mathrm{H} 4$ is fulfilled in four of the five cases (all but Italy). Spain and Portugal are the two cases where the weakening of the effect of national identification in 2014 is clearest, although in Spain the effect of national identification on European attachment was still significantly positive. In Greece, the slight positive effect of national attachment in 2004 is no longer significant either in 2014 or in 2017. However, even in Germany, the effect weakens significantly in 2014, although it remains positive. The 2017 figure for Germany and Portugal shows a trend towards the full recovery of the positive relationship prior to the Great Recession, since the 2017 effect is no longer significantly different from that of 2004. In Spain, by contrast, the weakening of the positive relationship still continued in 2017. Finally, Italy is the singular exception insofar as the 
effect of national attachment on European attachment was positive in 2004 and does not undergo major changes afterward.

\section{Discussion and Conclusions}

In this article, we examined the effects of the Great Recession on European Identification in the four Southern European countries and in Germany. Since we examined a limited number of cases, we were not able to empirically demonstrate the connections we suggest between the economic and political context of each of the five countries, on the one hand, and the statistical effects we show for our individual-level variables, on the other. However, as we warned in the introduction, we think that these connections are plausible under the light of the current theories of attitudes towards the EU that we revised here.

The Great Recession had a negative impact on European identification in the five countries under study: more moderate in the case of Germany, and deeper, especially during the peak of the Eurozone crisis, in the four Southern European countries. However, from 2014 onwards, European identification began to recover in Germany Spain and Portugal, reaching by 2017 levels similar to those prior to the crisis, while it stagnated at low levels in Greece and Italy. In order to explain these changes in attachment to Europe we resorted to three theoretical models: the rational-instrumental, the heuristic or institutional, and the identitarian approaches. Despite a certain parallelism between the evolution of the GDP and the patterns of recovery of European identification-this recovery is weaker where GDP growth has also been weaker: Italy and Greece, the microeconomic variables associated to the rational-instrumental approach, contribute surprisingly little to the explanation of European identification or its changes throughout the Great Recession.

By contrast, political and identification variables are more relevant to explain changes in European identification. However, these effects do not take place in a vacuum but were intermediated by the institutional crises that were triggered by the Great Recession in each of the five countries. These crises were very different in timing, intensity, and political consequences: it was very moderate in Portugal; somewhat greater in Germany and quite radical in Greece, Italy and Spain, even if in the latter case the negative consequences in terms of government instability were somewhat delayed. The impact of Euroscepticism has also varied greatly from country to country: it was largely irrelevant in Spain; moderate in Portugal; very relevant in Germany—but somewhat delayed and also linked to the 2015 refugee crisis - and great, affecting the whole spectrum of their respective party systems, in Italy and Greece. The particular traits of each case should be kept in mind in the following summing up of the multilevel evaluation effects and national identification effects across time and countries.

One the one had, in the observation closest to the peak of the Eurozone crisis, in 2014, substitution effects seemed to have played a key role in sustaining European identification when the latter was at its lowest level, particularly in Southern Europe. This key role of substituting effects in strengthening European identification is worth highlighting: it demonstrates that, even during the most serious institutional crisis suffered by the EU, a number of citizens were capable of evaluating the EU differently from their perceptions of national institutional performance and that such capacity reverted positively in their affective attachment to Europe. It ultimately also reflects some capacity by the EU to draw some legitimacy that is different from the legitimacy that it derives from its member states. This capacity might be due to the greater visibility of the EU during the Eurozone crisis, although did not provide any evidence in this chapter to confirm or refute this claim.

On the other hand, in Germany and Portugal-the two cases where the evaluations of the national government improved substantially, especially at the end of the period we examined-transfer effects were reinforced after the Great Recession, and particularly so in 2017, when European identification reached its highest level in these two countries. In other words, the relatively high levels of German and Portuguese affective attachment to Europe seems well entrenched on their positive evaluations of their national level, several 
years after the Eurozone crisis. Thus, to counterbalance the assertion made above, the EU's capacity to raise affective bonds on its own still seems rather limited.

Spain represents a singular case at the end of the period. Here, confidence only in the national government remained low, although there was a certain increase in double confidence that served to sustain European identification. Furthermore, in the absence of relevant Eurosceptic parties, there were fewer impediments for the recovery of European identification in this case. By contrast, in Italy and Greece, not only were government evaluations in the form of double confidence even lower than in Spain, but there were several relevant Eurosceptic parties that possibly also played a role in the stagnation of European identification in these two countries.

In this respect, our results also underline that despite the similar negative effect that the Great Recession initially had on European identification in the four Southern European countries-at least at the aggregate level—-these followed quite different patterns in the years after depending on their own political and institutional trajectories, to the extent that the pattern shown by Portugal after 2015 resembles more that of Germany than those of its three Southern European neighbours.

Finally, the radical transformation of party systems with the emergence of new Eurosceptic parties in Greece, Italy and Germany, as well as the radicalisation of previously Eurosceptic parties in Portugal, could not leave the positive embeddedness of European identification within national identifications unscathed. Here the effects are again greater in 2014, as the previous positive relationship disappears or weakens in four of the five cases. Thus the Great Recession shattered the reliance that the affective attitudes to Europe previously have had on their citizens' national ties and loyalties to their respective member states. This happened in Germany as it did in Southern Europe, revealing once again that changes in European identification during the Great Recession reflect varied political factors as much or even more than they do the economic consequences of the austerity policies. By 2017, the positive relationship had been fully restored in Germany and Portugal, signalling that the fading link between the two identifications might have been only temporary, at least in these two countries.

Author Contributions: Conceptualization, methodology, data curation, analysis, writing - original draft preparation, writing-review and editing, S.P.-N. and M.P. Both authors have read and agreed to the published version of the manuscript.

Funding: This article and its open access publication is based upon work funded by the Universidad Autónoma de Madrid and the Casa Velázquez in Madrid.

Institutional Review Board Statement: Ethical review and approval were waived for this study, due to the use of, already published, secondary quantitative anonymized data alone.

Informed Consent Statement: Not applicable.

Data Availability Statement: The data presented in this study are openly available in GESIS Leibniz Institute for the Social Sciences, at doi: 10.4232/1.10962 (EB62.0, study number ZA4229), doi: 10.4232/1.10968 (EB63.4 study number ZA4411), doi: 10.4232/1.10983 (EB67.1 study number ZA4529), doi: 10.4232/1.12050 (EB77.3 study number ZA5612), doi: 10.4232/1.12768 (EB80.1. study number ZA5876), doi: 10.3886/ICPSR36663.v1 (EB82.3, study number datasearch-httpwwwda-ra-deoaip-oaioai-da-ra-de562907), doi: 10.4232/1.13249 (EB84.3, study number ZA6643), doi: 10.3886/ICPSR36875.v1 (EB86.2, study number ZA6788), doi: 10.4232/1.13007 (EB88.3, study number ZA6928).

Acknowledgments: We would like to thank the Universidad Autonoma de Madrid and the Casa Velazquez for their support in funding this open access publication.

Conflicts of Interest: The authors declare no conflict of interest. 


\section{Appendix A}

Table A1. Description and measurement of the variables.

\begin{tabular}{|c|c|c|}
\hline Variables & Original Variable & Recodification \\
\hline European identification & $\begin{array}{l}\text { Please tell me how attached you feel to } \\
\text { Europe? } 1 \text { not at all attached; } 2 \text { not very } \\
\text { attached; } 3 \text { fairly attached; } 4 \text { very attached }\end{array}$ & $\begin{array}{l}\text { Binary variable recoded as: } \\
1 \text { fairly attached and very attached; } 0 \text { not at all } \\
\text { attached and not very attached }\end{array}$ \\
\hline National economy worse & $\begin{array}{l}\text { What are your expectations for the next twelve } \\
\text { months: will the next twelve months be better, } \\
\text { worse or the same, when it comes to the } \\
\text { economic situation in your country }\end{array}$ & $\begin{array}{c}\text { Binary variable recoded as: } \\
1 \text { will be worse; } 0 \text { will be the same and will be } \\
\text { better }\end{array}$ \\
\hline Personal economy worse & $\begin{array}{l}\text { What are your expectations for the next twelve } \\
\text { months: will the next twelve months be better, } \\
\text { worse or the same, when it comes to your } \\
\text { personal job situation }\end{array}$ & $\begin{array}{c}\text { Binary variable recoded as: } \\
1 \text { will be worse; } 0 \text { will be the same and will be } \\
\text { better }\end{array}$ \\
\hline Unemployed & $\begin{array}{l}\text { Did you do any paid work in the past? What } \\
\text { was your last occupation? }\end{array}$ & $\begin{array}{c}\text { Binary variable recoded as: } \\
1 \text { unemployed; } 0 \text { employed, self-employed, } \\
\text { student, retired and housekeeper }\end{array}$ \\
\hline Higher education & $\begin{array}{l}\text { How old were you when you stopped } \\
\text { full-time education? }\end{array}$ & $\begin{array}{l}\text { Binary variable recoded as: } \\
1 \text { twenty years or higher; } 0 \text { individuals with no } \\
\text { full-time education and } 19 \text { years or lower }\end{array}$ \\
\hline $\begin{array}{l}\text { Confidence in the national government, the } \\
\text { EU, in both, and in neither }\end{array}$ & $\begin{array}{l}\text { For each of the following institutions, please } \\
\text { tell me if you tend to trust it or tend not to } \\
\text { trust it: (a) The National Government. (b) The } \\
\text { European Union }\end{array}$ & $\begin{array}{l}1 \text { trust in National Government and not trust } \\
\text { in EU; } 2 \text { trust in the EU and not trust in } \\
\text { National Government; } 3 \text { trust in National } \\
\text { Government and trust in EU; } 4 \text { not trust in } \\
\text { National Government and not trust in EU }\end{array}$ \\
\hline National attachment & $\begin{array}{l}\text { Please tell me how attached you feel to your } \\
\text { country? }\end{array}$ & $\begin{array}{l}\text { Binary variable recoded as: } \\
1 \text { fairly attached and very attached; } 0 \text { not at all } \\
\text { attached and not very attached }\end{array}$ \\
\hline Age & How old are you? & $15-99$ \\
\hline Woman & Gender & $\begin{array}{l}\text { Binary variable recoded as: } \\
1 \text { woman; } 0 \text { man }\end{array}$ \\
\hline Ideology & $\begin{array}{l}\text { In political matters people talk of "the left" } \\
\text { and "the right". How would you place your } \\
\text { views on this scale? }\end{array}$ & 1-10 scale: 1 left; 10 right \\
\hline Year & Year of the survey & $2004 ; 2014 ; 2017$ \\
\hline
\end{tabular}

Source: Own elaboration based on Eurobarometer.

Table A2. Descriptive statistics of all variables.

\begin{tabular}{|c|c|c|c|c|c|}
\hline Variables & Obs & Mean & Std. Dev. & Min & Max \\
\hline European identification & 16,724 & 0.593219 & 0.491248 & 0 & 1 \\
\hline National economy worse & 16,330 & 0.38316 & 0.486172 & 0 & 1 \\
\hline Personal economy worse & 15,851 & 0.178664 & 0.383083 & 0 & 1 \\
\hline Unemployed & 16,974 & 0.093025 & 0.290476 & 0 & 1 \\
\hline Higher education & 16,654 & 0.271106 & 0.444544 & 0 & 1 \\
\hline $\begin{array}{c}\text { Confidence in the national government, the EU, in both, } \\
\text { and in neither }\end{array}$ & 14,978 & 3.000134 & 0.882039 & 1 & 4 \\
\hline National attachment & 16,927 & 0.933361 & 0.249403 & 0 & 1 \\
\hline Age & 16,974 & 49.27407 & 18.36506 & 15 & 95 \\
\hline Woman & 16,974 & 0.531519 & 0.49902 & 0 & 1 \\
\hline Ideology & 13,397 & 4.937374 & 1.990956 & 1 & 10 \\
\hline Year & 16,974 & 2011.714 & 5.541954 & 2004 & 2017 \\
\hline
\end{tabular}




\section{References}

Abdelal, Rawi, Yoshiko M. Herrera, Alastair Iain Johnston, and Rose McDermott. 2009. Identity as variable. In Measuring Identity. A Guide for Social Sciences. Edited by Rawi Abdelal, Yoshiko M. Herrera, Alastair Iain Johnston and Rose McDermott. Cambridge: Cambridge University Press.

Alvarez-Miranda, Berta. 1994. Integración europea y sistemas de partidos en el sur de Europa: Despolarización y Convergencia. Revista de Estudios Políticos 85: 143-67.

Anderson, Christopher J. 1998. When in Doubt, Use Proxies: Attitudes toward Domestic Politics and Support for European Integration. Comparative Political Studies 31: 569-601. [CrossRef]

Ares, Macarena, Besir Ceka, and Hanspeter Kriesi. 2017. Diffuse support for the European Union: Spillover effects of the politicization of the European integration process at the domestic level. Journal of European Public Policy 24: 1091-15. [CrossRef]

Braun, Daniela, and Markus Tausendpfund. 2014. The Impact of the Euro Crisis on Citizens' Support for the European Union. Journal of European Integration 36: 231-45. [CrossRef]

Bruter, Michael. 2003. Winning Hearts and Minds for Europe: The Impact of News and Symbols on Civic and Cultural European Identity. Comparative Political Studies 36: 1148-79. [CrossRef]

Bruter, Michael. 2005. Citizens of Europe? The Emergence of a Mass European Identity. Houndmills: Palgrave Macmillan.

Carey, Sean. 2002. Undivided Loyalties: Is National Identity an Obstacle to European Integration? European Union Politics 3: 387-413. [CrossRef]

Cerutti, Furio, and Sonia Lucarelli. 2008. The Search for a European Identity. Values, Policies and Legitimacy of the European Union. New York: Routledge.

Checkel, Jeffrey T., and Peter J. Katzenstein. 2009. European Identity. Cambridge: Cambridge University Press.

Cram, Laura. 2009. Introduction: Banal Europeanism: European Union Identity and National Identities in Synergy. Nations and Nationalism 15: 101-8. [CrossRef]

de Vries, Catherine. E. 2018. Euroscepticism and the Future of European Integration. Oxford: Oxford University Press.

de Vries, Catherine. E., and Kees van Kersbergen. 2007. Interests, Identity and Political Allegiance in the European Union. Acta Politica 42: 307-28. [CrossRef]

Díez Medrano, Juan. 2003. Framing Europe: Attitudes to European Integration in Germany, Spain and the United Kingdom. Princeton: Princeton University Press.

Dotti Sani, Giulia M., and Beatrice Magistro. 2016. Increasingly unequal? The economic crisis, social inequalities and trust in the European Parliament in 20 European countries. European Journal of Political Research 55: 246-64. [CrossRef]

Eichenberg, Richard C., and Russell. J. Dalton. 1993. Europeans and the European Community: the dynamics of public support for European integration. International Organization 47: 507-34. [CrossRef]

Fernández, Juan J., Monika Eigmüller, and Stefanie Börner. 2016. Domestic transnationalism and the formation of pro-European sentiments. European Union Politics 17: 457-81. [CrossRef]

Fuchs, Dieter. 2011. Cultural diversity, European identity and legitimacy of the EU: A theoretical framework. In Cultural Diversity, European Identity and the Legitimacy of the EU. Edited by Dieter Fuchs and Hans-Dieter Klingemann. Glos: Edward Elgar Publishing.

Gabel, Matthew. 1998. Public Support for European Integration: An Empirical Test of Five Theories. The Journal of Politics 60: 333-54. [CrossRef]

Hobolt, Sara B., and Catherine E. de Vries. 2016. Public Support for European Integration. Annual Review of Political Science 19: 413-32. [CrossRef]

Hobolt, Sara B., and James Tilley. 2014. Blaming Europe. In Blaming Europe?: Responsibility Without Accountability in the European Union. Oxford: Oxford University Press.

Hooghe, Liesbet, and Gary Marks. 2005. Calculation, Community and Cues: Public Opinion on European Integration. European Union Politics 6: 419-43. [CrossRef]

Hooghe, Liesbet, and Gary Marks. 2008. European Union? West European Politics 31: 108-129. [CrossRef]

Isernia, Pierangelo, Irena Fiket, Fabio Serricchio, and Bettina Westle. 2012. But it still it does not move: Functional and identity-based determinants of European identity. In Citizens and the European Polity: Mass Attitudes towards the European and National Polities. Edited by David Sanders, Pedro Magalhaes and Gabor Tóka. Oxford: Oxford University Press.

Kriesi, Hanspeter, Edgar Grande, Romain Lachat, Martin Dolezal, Simon Bornschier, and Timotheos Frey. 2006. Globalization and the transformation of the national political space: Six European countries compared. European Journal of Political Research 45: 921-56. [CrossRef]

Malmborg, Mikael. A. 2002. The Dual Appeal of Europe in Italy. In The Meaning of Europe: Variety and Contention Within and Among Nations. Edited by Mikael af Malmborgc and Bo Strath. Oxford: Berg.

McLaren, Lauren. M. 2006. Identity, Interest and Attitudes to European Integration. New York: Palgrave Macmillan.

Moravcsik, Andrew. 2012. Europe After the Crisis How to Sustain a Common Currency. Foreign Affairs 91: 54-68.

Niedermayer, Oskar, and Bettina Westle. 1995. A typology of orientations. Public Opinion and Internationalized Governance. In Public Opinion and Internationalized Governance. Edited by Oskar Niedermayer and Ricahrd Sinnott. Oxford: Oxford University Press.

Orriols, Luis, and Guillermo Cordero. 2016. The breakdown of the Spanish two-party system: the upsurge of Podemos and Ciudadanos in the 2015 general election. South European Society and Politics 21: 469-92. [CrossRef] 
Otjes, Simon, and Alexia Katsanidou. 2017. Beyond Kriesiland: EU integration as a super issue after the Eurocrisis. European Journal of Political Research 56: 301-19. [CrossRef]

Paradés, Marta, Teresa Mata, and Santiago Pérez-Nievas. 2013. Las actitudes hacia la UE en el contexto de crisis: España, 2007-2012. Panorama Social 17: 101-20.

Rama, José. 2019. Partidos y sistemas de partidos en Europa occidental después de la Gran Recesión: ¿cuánto cambio? Doctoral dissertation, Universidad Autónoma de Madrid, Madrid, Spain.

Ray, Leonard. 2003. Reconsidering the Link between Incumbent Support and Pro-EU Opinion. European Union Politics 4: 259-79. [CrossRef]

Risse, Thomas. 2010. A Community of Europeans? Transnational Identities and Public Spheres. Ithaca: Cornell University Press.

Rohrschneider, Robert. 2002. The Democracy Deficit and Mass Support for an EU-Wide Government. American Journal of Political Science 46: 463-75. [CrossRef]

Sánchez-Cuenca, Ignacio. 2000. The Political Basis of Support for European Integration. European Union Politics 1: 147-71. [CrossRef]

Sanders, David, Paolo Bellucci, Gabor Tóka, and Mariano Torcal. 2012. The Europeanization of National Polities? Citizenship and Support in a Post-Enlargement Union. New York: Oxford University Press.

Serricchio, Fabio, Myrto Tsakatika, and Lucia Quaglia. 2013. Euroscepticism and the global financial crisis. Journal of Common Market Studies 51: 51-64. [CrossRef]

Sinnott, Richard. 2005. An Evaluation of the Measurement of National, Subnational and Supranational Identity in Crossnational Surveys. International Journal of Public Opinion Research 18: 211-23. [CrossRef]

Soares, Antonio G. 2007. Portugal and the European union: The ups and downs in 20 years of membership. Perspectives on European Politics and Society 8: 460-75. [CrossRef]

Torcal, Mariano, and Pablo Christmann. 2018. Congruence, national context and trust in European institutions. Journal of European Public Policy 26: 1-20. [CrossRef]

Treib, Oliver. 2014. The voter says no, but nobody listens: Causes and consequences of the Eurosceptic vote in the 2014 European elections. Journal of European Public Policy 21: 1541-54. [CrossRef]

Tsoukalas, Constantine. 2002. The Irony of Symbolic Reciprocities-The Greek Meaning of "Europe" as a Historical Inversion of the European Meaning of "Greece". In The Meaning of Europe: Variety and Contention Within and Among Nations. Edited by Mikael af Malmborg and Bo Strath. Oxford: Berg.

Verney, Susannah. 2017. Losing loyalty: the rise of polity euroscepticism in Southern Europe. In The Routledge Handbook of Euroscepticism. Edited by Benjamin Leruth, Nicholas Startin and Simon Usherwood. New York: Routledge.

Westle, Bettina, and Paolo Segatti, eds. 2016. European Identity in the Context of National Identity. Questions of Identity in Sixteen European Countries in the Wake of the Financial Crisis of 2007 and 2009. Oxford: Oxford University Press. 